UDC 94:304.4(477+438)

DOI: $10.20535 / 2307-5244.45 .2017 .117735$

\title{
L. Shpakovskyi
}

National Technical University of Ukraine "Igor Sikorsky Kyiv Polytechnic Institute»

Л. В. Шпаковськи

Національний технічний університет Украӥни «Київський політехнічний інститут імені Ігоря Сікорського»

\section{CULTURAL AND HUMANITARIAN COOPERATION BETWEEN UKRAINE AND POLAND AS AN INSTRUMENT OF ESTABLISHING INTERSTATE DIALOGUE Культурно-гуманітарна співпраця між Украӥною та Польщею як інструмент у налагодженні міждержсквнгго діалогу}

The study provides a retrospective analysis of the problem of establishing the interstate dialogue between Ukraine and Poland based on cultural and humanitarian cooperation since the beginning of the 1990s.

The author proves that cooperation between Ukraine and Poland in the field of science, education and art has been dynamic. Poland actively involves Ukrainian students, academics, scholars in its educational process. It shares experience in introducing innovations and reforming the field of education. The key projects of cooperation in the field of science are analyzed.

Cultural and artistic cooperation involves festivals, exhibitions of works of Ukrainian artists in Poland and vice versa, tours of amateur and professional groups.

The historical memory still is a very substantial element of bilateral relations, and it is explained very differently by historiography in those two countries. From time to time it leads to deterioration in relations between Ukraine and Poland

The scientific approach to the historical experience of the two states is analyzed retrospectively. The important aspects of assessing the past events (in particular, the Volyn tragedy and the "Visla» operation), guardianship of Ukrainian and Polish burials, protection of rights of the Ukrainians in Poland and the Poles in Ukraine are studied. Despite the successful steps of both states towards historical reconciliation, the future development of this process was and remains ambiguous. However, due to political will and consistency of decisions, Ukraine and Poland have the opportunity to overcome the existing contradictions and strengthen cooperation in various spheres of interstate cooperation. 
Keywords: Ukraine, the Republic of Poland, cultural and humanitarian cooperation, cultural diplomacy.

У дослідженні робиться ретроспективний аналіз проблеми налагодження міждержавного діалогу між Україною та Польщею на прикладі культурно-гуманітарної співпраиі з поч. 1990-х рр. і дотепер.

Доводиться, що найбільш динамічно розвивається співпраия Украйни $i$ Польщі в галузі науки, освіти та мистецтва. Польща активно залучає українських студентів, викладачів, науковиів у свої навчальні прочеси, ділиться досвідом запровадження інноваиій та реформування освітньої сфери. Розглядаються показові проекти наукової взаємодії.

Важливою складовою у розвитку міждержавних відносин залишається проблема історичної пам'яті, що трактується в історіографії обох держав по-різному. Час від часу це стає причиною загострення стосунків Украӥни та Польщі. Робиться ретроспективний аналіз спроб наукового осмислення історичного досвіду двох держав. Аналізуються такі важливі аспекти, як оцінка подій минулого (зокрема, Волинської трагедії та операиії «Вісла»), опіка над українськими і польськими похованнями, захист прав українців у Польщі й поляків в Украӥні. Попри успішні кроки обох держав до історичного примирення, подальший шлях ијього процесу був $і$ залишається неоднозначним. Утім, завдяки політичній волі та послідовності рімень Україна і Польща мають змогу подолати існуючі суперечності й укріплювати співпрацю у різних сферах державної взаємодіі.

Ключові слова: Україна, Республіка Польща, культурно-гуманітарне співробітництво, культурна дипломатія.

Cultural and humanitarian cooperation is an important trend in interstate relations. Establishing connections in the fields of science, religion, education, culture and art is sure to contribute to the enhancement of interaction and cooperation in other areas - political, diplomatic, trade and economic, and security. «Cultural diplomacy» has a huge potential for influencing the formation of the international image of the country, strengthening its national identity on the world stage, and stimulating the development of culture in the country. Since the 1990's, the formation and involvement of the cultural component of the foreign policy of our state in relations with other countries has undergone significant transformations due to both external and internal factors. Most strikingly, these transformations can be traced on the example of Ukraine's relations with the Republic of Poland, our closest western neighbor. Over the past decades, both countries have tried to rethink the difficult historical past of our relations, to establish an active and 
constructive interstate dialogue. The analysis of cultural aspect of relations between Ukraine and Poland is the subject of this article.

The works of such national scholars as N. Zavintnevych (Завітневич, Н. 2008), V. Lyshko (Лишко, В. 2002), N. Medvedchuk (Медведчук, Н. 2001) are devoted to issues of relations between Ukraine and Poland, as well as to cultural and humanitarian factors in the interstate dialogue. In O. Znakhorenko's dissertation «Strategic Partnership in Ukrainian-Polish Relations» (Знахоренко, O. 2005) the Ukrainian-Polish cooperation in the humanitarian field, as well as the influence of historical stereotypes on contemporary interethnic relations are studied. V. Strelchuk researched the issues of cross-border cultural cooperation between Ukraine and Poland (Стрельчук, В. 2015). Among recent studies, articles by V. Nakonechnyi should be considered (Наконечний, В. 2015). Bilateral relations are not out of the attention of Polish scholars. Thus, the issues of the interaction between Poland and Ukraine, as well as the place of both states in foreign policy, are studied by K. Fedorovych (Федорович, К. 2004), Т. Olshanskyi (Ольшанський, T. 2002) and other scientists.

The chosen theme is well-researched by national experts. Nevertheless, the importance of Ukrainian-Polish relations for Ukraine in the situation of determination of its European choice will actualize the study of positive and problematic aspects of the bilateral relations. The purpose of this article is to analyze the development of cultural and humanitarian cooperation (in particular in such fields as science, education, medicine, religion, assessment of historical events).

The new page of centuries-old complex relations between Ukraine and Poland began in the early 1990's. In April 1990, the newspaper «Życie Warszawy» wrote that «brotherly relations between the Ukrainian and Polish peoples» should be established (Зленко, А. 2004, с. 466). On December 2, 1991, the Republic of Poland was the first country in the world to recognize Ukrainian independence, and on January 4, 1992, diplomatic relations were established between the states. In his address to the Polish Sejm on May 8, 1992, the Polish Foreign Minister spoke about relations with Ukraine as «promising and free from historical burdens» as «breakthrough success of the new Polish democracу» (Зленко, А. 2004, с. 466).

During this period, the legal and contractual basis of bilateral relations was established. In 1991-1993, about 50 intergovernmental documents were signed to govern relations in political, trade, economic, cultural, humanitarian and other spheres. During the first official visit of President of Ukraine Leonid Kravchuk to the Republic of Poland on May 18-19, 1992, the Treaty on Neighborhood, Friendly Relations and Cooperation between the two countries was signed. This document laid foundations for further cooperation of our states, including one in cultural and humanitarian field. It declared the desire of both parties to promote cooperation 
in the field of culture, education and science, to expand cultural exchange, cooperation between cultural institutions and organizations, to maintain direct contacts between artists, to facilitate exchange of scholars, teachers, students, graduate students and fellows, as well as to conduct joint researches (Договір між Україною і Республікою... 1992). In addition, Article 11 of the Treaty emphasized the right of members of the Polish national minority in Ukraine and the Ukrainian national minority in Poland to preserve, express and develop their ethnic, cultural, linguistic and religious identity. In 1997, the Neighborhood Treaty was reinforced by signing two important documents - the Agreement between the Government of Ukraine and the Government of the Republic of Poland on Cooperation in the Sphere of Culture, Science and Education (May 20, 1997) and the Agreement on Cooperation in the Field of Protection and Return of Cultural Property Lost and Illegally Transported during World War II (May 25, 1997). In the 2000 's, the contractual and legal framework for bilateral relations was supplemented by the Agreement on Cooperation between the State Committee of Archives of Ukraine and the Directorate General of the Archives of the Republic of Poland in the field of archival affairs (October 17, 2008), as well as the Agreement on Cooperation in Education between the Ministry of Education and Science of Ukraine and the Ministry of National Education of the Republic of Poland (January 19,2015$)$. Currently these documents govern cultural and humanitarian cooperation between our states.

According to the Agreement on Cooperation in the field of Culture, Science and Education of May 20, 1997, the main priorities of interstate cooperation are «exchange of scientific information, educational and scientific cooperation, conducting joint research in various fields of science, joint conferences, symposiums, seminars, internship practices of foreign teachers, students, foreign publication in professional editions, translation of monographs, promotion of education of national minorities, establishment of partnership between universities» (Угода... 1992). Indeed, since the mid-1990s, the number of mutual traineeships for scholars, lecturers and postgraduates has been steadily increasing. Thus, for example, in 1993, the scientific institutions of the Russian Academy of Sciences welcomed 253 Polish scientists. In 1994, the number of Polish scientists who worked in Ukraine, reached 453 people (Стрільчук, Л., Стрільчук, В. 2013, с. 144). Such educational institutions as the Lesya Ukrainka Eastern European National University and the Maria Curie Skłodowska University in Lublin were actively involved in these processes. By the mid-2000s more than 100 universities and other educational institutions had been cooperating with the Polish side.

Poland responded promptly and sincerely to the events of 2014 in Ukraine. According to the data of the Embassy of Ukraine in the Republic of Poland, in the 
2014-2015 academic year, 381 students and 50 postgraduates from Ukraine, mainly from the ATO region and the ARC, arrived to study at Polish universities at the expense of Poland (Культурно-гуманітарне...). According to various estimates, in 2016 at universities and academies of Poland, from 12 thousand to 16 thousand Ukrainians studied (Культурно-гуманітарне...).

One of the most interesting projects of scientific cooperation is the initiative of the Polish side launched in 2000 - the European Collegium of Polish and Ukrainian Universities with its center in Lublin. It consists of the Maria Curie Skłodowska University, the John Paul II Catholic University of Lublin, the Agricultural and Medical Academy (Lublin), the Lublin Polytechnic, the National Taras Shevchenko University of Kyiv, the Ivan Franko National University of Lviv and the National University of «Kyiv-Mohyla Academy». Based on the European Collegium, Ukrainian and Polish scholars had the opportunity to work together, to improve their educational level. Over the period of its operation, more than 100 Doctors of Philosophy (Candidates of Sciences) graduated from the European Collegium. The key areas of work of the European Collegium were humanitarian disciplines - history, political science, philosophy, philology, law. Subsequently, these areas were supplemented by medicine and chemistry. This project lasted for 10 years and demonstrated a successful example of intergovernmental cooperation in the field of science, but due to organizational and financial complexity, in 2011, it ceased to exist and was transformed into a new structure the Eastern Europe Studies Centre.

There was cooperation in other scientific fields, in particular, as of 1999, the cooperation program included 54 joint scientific projects, including in the areas of innovations and technologies (Стрільчук, Л., Стрільчук, В. 2013, с. 148). Implementation of these projects was undertaken by such institutions as Ivan Franko National University of Lviv, Ivan Fedkovych Chernivtsi National University, Lviv Polytechnic National University, Lesya Ukrainka Volyn State University, Institute of Geochemistry of the National Academy of Sciences of Ukraine, etc. In subsequent years, the number of joint scientific projects increased, became more diverse. In June 2004, the exhibition of scientific and technical achievements «Ukraine-Poland: Strategic Partnership in the Field of Science and Technology» was held in Lviv and Kyiv, where 25 scientific institutions and higher educational establishments from Ukraine and 15 scientific institutions and higher educational establishments from Poland took part. Regular sessions of the Joint Ukrainian-Polish Commission on Scientific and Technical Cooperation are held. Since 2008, the Ukrainian-Polish Center and Forum of Rectors of Higher Technical Institutions of Ukraine and the Republic of Poland have been operating on the basis of the National Technical University «Igor Sikorsky Kyiv Polytechnic Insti- 
tute». Under the initiative of the Forum, with the support of the Ministry of Education and Science of Ukraine and the Ministry of Science and Higher Education of the Republic of Poland in April 2017, the Ukrainian-Polish Days of Education, Science and Innovations took place on the basis of the KPI. The Polish delegation consisted of more than 250 representatives, including rectors and vicerectors of Polish technical universities. The main issues considered at the Forum were international cooperation in the field of innovative technologies and network start-ups, acceleration of innovations in Polish and Ukrainian universities, internationalization of Polish and Ukrainian universities, introduction of double diplomas and development of contacts within the framework of Erasmus + program (Українсько-польські дні... 03.04.2017).

The 1990s became the period of attempts at scientific understanding of bilateral relations, their uneasy historical experience. Thus, since 1995, scientific conferences devoted to such complex issues as «Volyn in World War II and Post-War Years» (Lutsk, April 1995), «Ukrainian-Polish Relations in Galicia in the $20^{\text {th }}$ Century» were held on a permanent basis in the territory of both countries (Ivano-Frankivsk, November 1996), «Ukraine-Poland: Yesterday, Today, Tomorrow» (Lublin, June 1997), «The Poles and the Ukrainians: 1918-1956» (Sanok, November 1997), «Ukrainian-Polish Relations in the $20^{\text {th }}$ Century: Statehood, Society, Culture» (Ternopil, April 1999) and other. Since 1995, due to the efforts of historians of the Lesya Ukrainka Volyn State University (Lutsk) and their colleagues from the Military Historical Institute (Warsaw) regular international scholarly workshops related to the history of Ukrainian-Polish relations have been held. During 1996-2001, 10 seminars were held in Warsaw and Lutsk. Representatives of both universities made a huge contribution to the research, establishment and improvement of Ukrainian-Polish relations. We agree with V. Strelchuk's view that as a model and a guide for the broad social strata, the members of education and science communities took up a difficult task of smoothing the sharp edges of Ukrainian-Polish relations, expanding the scientific and educational contacts of the two nations, and thereby deepening the integration of the two societies (Стрільчук, Л. Стрільчук, В. 2013, с. 72). Undoubtedly, due to the scholars, many crucial and important steps have been taken in this direction that resulted in positive development of bilateral relations in various spheres.

On April 11, 2005, the Agreement on Mutual Recognition of Academic Diplomas and Degrees was signed between the Cabinet of Ministers of Ukraine and the Government of the Republic of Poland. Thus, in the scientific and educational direction since the 1990s, there is steady positive dynamics, the revival of contacts and attempts to rethink the historical heritage of the common past.

Active interaction took place in the field of medicine. Since the mid-1990s, 
medical conferences have been held regularly to share experiences and apply the latest technology. With the efforts of such organizations as the Volyn Society of Doctors of Polish Origin, the Ukrainian Medical Society in Lviv, the Ministry of Health of Ukraine, Ukrainian doctors were trained in Polish polyclinics and hospitals. Thus, in November 2000, 10 doctors from Kyiv, Zhytomyr, Lutsk, Vinnytsia and Khmelnytskyi were trained at the Pope John Paul II Voivodeship Hospital in Zamości (Стрільчук, Л. Стрільчук, В. 2013, с. 73), during which they studied both the achievements of Polish medicine in various fields and the experience of health care system reforming in Poland. In 2012, a joint conference on palliative and hospice medicine took place in Lutsk under the patronage of the Consulate General of the Republic of Poland in Lutsk. In 2014, due to events in Ukraine, an initiative group of doctors of Ukrainian origin living and working in different European countries proposed to establish the program of Ukrainian-Polish internship. This project was supported by the Ministry of Health of Ukraine and the Ministry of Health of the Republic of Poland (Польсько-українська програмa... 26.01.2016). The main goal of the program was to familiarize Ukrainian doctors with the level and capacities of the Polish health system, methods of diagnosis, treatment and rehabilitation of so-called diseases of civilization (chronic noninfectious diseases). The program was attended by more than 500 doctors, nurses and students of medical faculties from Ukraine. The main objective of the project was to familiarize Ukrainian doctors with the experience of transforming the post-Soviet health system into the European system, as well as launch the Polish Erasmus + project for students of medical faculties from Ukraine.

However, this cooperation has reverse effects - a drain of medical personnel from Ukraine. Since the beginning of the 2010s, when Polish programs to attract practicing doctors, nurses and students from medical faculties to training, internships and employment in Poland and other EU countries intensified, thousands of specialists left Ukraine in search for better luck and decent wages. Thus, according to some data from the beginning of the 2010s, in Ukraine, 7-8 thousand doctors leave every year (Лікарі на експорт... 20.02.2013). The most attractive for Ukrainian doctors are Russia, Poland, Slovakia, the Czech Republic and Germany. For example, in Poland in 2014 there were registered 3,452 doctors of Ukrainian origin. Moreover, in Germany in 2011, the number of doctors from Ukraine was 821, in 2012 — already 922 (Лікарі на експорт ...20.02.2013). Since 2014, due to events in the Eastern Ukraine and a sharp drop in living standards, the number of people leaving Ukraine, including medical personnel, has increased. Nevertheless, the interaction of Ukraine and Poland in the medical sphere is fruitful. It allows Ukrainian specialists to become involved in modern technologies and experience in reforming the health care system. 
The cooperation in the field of youth policy and sports is dynamic. Since the conclusion of the Agreement between the Government of the Republic of Poland and the Government of the Ukrainian SSR of June 22, 1991, the youth cooperation and youth exchanges in the form of youth contacts have become more diverse, and the number of exchanges has increased among schoolchildren, students, members of youth organizations and societies. Joint seminars, conferences, tournaments, summer camps are held regularly by youth organizations of Ukraine and Poland. In November 1996, youth organizations of the Lviv Region, Volyn and the Eastern Border Regions of Poland launched the «Youth of the Euroregion Bug» project, within which more than 50 youth programs in cultural and historical, educational, recreational areas were implemented and attended by hundreds of young people from Ukraine, Poland and Belarus. Among the joint youth projects, the following should be named: «Academy of Local Development in Ukraine», «PolishAmerican-Ukrainian Cooperation Initiative» (PAUCI), «Sharing Successful Polish Experience in Small and Medium-Sized Enterprises Management», etc. Members of non-governmental youth organizations on a voluntary basis are engaged in educational, social, representative, legal, patriotic, cultural and artistic, environmental and public activities.

Members of the Ukrainian Plast and the Związek Harcerstwa Polskiego actively interact. For 20 years there is the summer camp of the Zwiazek Harcerstwa Polskiego near the village of Kostiukhnivka (the Volyn region) where Polish and Ukrainian youth learn Ukrainian, join our traditions and strengthen Ukrainian-Polish ties. In addition to the rest, members of the Związek Harcerstwa Polskiego perform a very important task - they are taking care of the tombstones in the soldier's cemetery of Polish legionnaires, Yuri Pilsudskyi, who died in 1916 in battles with the Russian army. In turn, members of the Ukrainian Plast for many years have been caring for the graves of UIA soldiers in Poland. Similar camps operate in Poland, as well as in the Lviv and Volyn regions. An interesting scout movement, known as the Bethlehem Fire of Peace, is the spread of the symbolic fire lit on Christmas at the birthplace of Jesus Christ. For the first time in the territory of Ukraine, the Bethlehem Fire from Poland was transferred back in 1992; however, the official counting of this initiative has been carried out since 1998, when the Polish hackers handed fire to the members of the Ukrainian Plast at the customs passage of Rava-Ruska-Grebenne (Historia harcerstwa...). Since then, these activities are carried out annually. Consequently, youth exchanges are a very important factor in establishing inter-state relations, raising awareness of the peculiarities of our countries among the public.

Cultural and artistic cooperation between Ukraine and Poland is active. Since 1991, Days of Ukrainian Culture in Poland and Days of Polish Culture in Uk- 
raine have become regular. For the first time, the Days of Ukrainian Culture in Poland were held on December 6-8, 1991, shortly after the recognition of independence of our state by Poland. The experience of representing in Poland some regions of Ukraine is quite interesting. In particular, in September 1993 Warsaw hosted the Volyn Days; in October 1995, the Lviv Youth Days took place in Krakow. Days of Ukraine in different years were held in Sopot, Gdynia, Gdansk. In turn, the Days of Polish Culture were held in Kyiv (1995), Lutsk (1996), Lviv (1997). However, the most significant events concerning the acquaintance of our countries with the culture of each other were the Year of Poland in Ukraine (2004) and the Year of Ukraine in Poland (2005). The catching events of this period were the exhibition of the Polish poster in the Lviv Palace of Arts, the exhibition of Polish artists «Zanurennia» in Kyiv, exhibitions of Polish sculptors in Ternopil, Lviv, Ivano-Frankivsk, and Lutsk. In 2015, in Warsaw, exhibitions of Ukrainian artists Ivan Marchuk and Matvii Weisberg took place.

An important form of good-neighborly interaction is the tour activities of professional and amateur creative teams of Ukraine and Poland. The tour activity helps to make the neighbors aware of cultural heritage and traditions. Children, youth, folk, church, musical, jazz and other festivals with the participation of Ukrainian and Polish groups have become widespread since the early 1990's. Among the most striking events, such festivals as «Polish Summer with Folklore», «On the Waves of the Svitiaz» and «Berehynia» (Lutsk), «Kyiv. Music. Fest», «O-Fest» (Kyiv), «Ukrainian-Polish Partnership Festival» (Lviv), «Galicia» (Krasicini castle), Ukrainian culture festival in Sopot, «Ukrainian Spring Festival» (Poznan), «Lemky Festival» (Zhdynya) and «Bytiv Varta» (Bytiv) and others.

Often, there is a tour to Poland of the M. Zankovetska National Academic Ukrainian Drama Theatre, the Kyiv National Academic Operetta Theater, the P. K. Saksaganskyi Kyiv Academic Regional Music and Drama Theater, the Odessa National Academic Theater of Opera and Ballet, and others. In April 2017, during the Ukrainian-Polish days of education, science and innovation in Kyiv, a concert was held with the participation of the best artistic groups of Polish and Ukrainian universities, a special guest being Polish singer Moshe Kasher, the finalist of the Eurovision Song Contest 2017. Thus, artistic cooperation is one of the most convenient ways to share with other countries its cultural achievements and traditions.

The visit of Pope John Paul II, a Pole, was of great importance for the development of Ukrainian-Polish relations. According to Anatolii Zlenko (the First Minister for Foreign Affairs of Ukraine), this visit on June 23-27, 2001 followed the hard work of Ukrainian diplomats (Зленко, А. 2004, с. 495). Official diplomatic relations between Ukraine and the Holy See were established on February 8, 1992, 
and the first meeting at the level of Heads of State took place in May 1995, when Ukrainian President Leonid Kuchma met with the Pope during his state visit to Italy. Then the parties agreed on the forthcoming visit of John Paul II to Ukraine, but taking into account the difficult religious situation in Ukraine and the necessary preparation of the society to this, a date of the visit was not decided. In 6 years since the agreement on the visit and the visit, Ukraine has undergone significant changes, political, and above all, social. Nevertheless, the decision of the President of Ukraine on the state visit of the Pope to Ukraine was rather complicated and was supported by the assurance that the Ukrainians will meet him positively and warmly (Зленко, А. 2004, c. 496). Despite the fact that Pope John Paul II was recognized as the Pope who travelled more than any other Pope in the history of the Holy See, the countries competed for the right to welcome the Pope. That is why it was so important for Ukraine to hold a meeting of the head of the Holy See at the highest level, taking into account the experience of Poland, as well as the Orthodox Greece and Georgia, who visited the Pope in Ukraine. The purpose of the visit of John Paul II was to support Catholics in their faith and to help establish friendly relations between different confessions in Ukraine. During his visit, the Pope visited Kyiv and Lviv, served 4 liturgies (2 in Latin and 2 in the Byzantine style), delivered 11 sermons and speeches, as well as met with representatives of the All-Ukrainian Council of Churches (it should be mentioned that the UOC-MP representatives did not attend the meeting). According to various estimates, from 2,5 to 5 million people, including several thousand Ukrainian and foreign journalists, took part in the events (Візит папи... 02.07.2001). Ukrainian politicians and diplomats marked the commitment of John Paul II to Ukraine. The visit of the Pope to Ukraine has made a positive impetus for the further establishment of the relations between Ukraine and Poland on a religious basis. Thus, the Lviv region is a territory of pilgrimage and constant close cooperation between Ukrainian and Polish communities. The Roman Catholic Church in Lviv is the center of Polish culture and spirituality, and the residence of the Roman Catholic Bishop, the center for coordinating cross-border cooperation between Catholics of Ukraine and Poland.

Ukrainian and Polish religious communities conduct joint religious events, organize pilgrimages to holy places, in particular, to Unev (Peremyshl district), Krekhiv (Zhovkva district) and Zarvanytsi (Ternopil region). The Ukrainian Catholics, in turn, visit the shrines located on the Polish territory - Kalvarija Patslavska (Peremyshl), Częstochowa (Krakow), Lednice and others. The cooperation is established between theological educational institutions of Ukraine and Poland. The key institutions in this collaboration are the Ukrainian Catholic University (Lviv) and the Catholic University of Lublin. Many Ukrainian students study theology 
and philosophy at the Lublin Catholic University, gaining master's degree, PHD degree there and returning to work in Ukraine (Щурко, У. 2014, c.179). There is an exchange of teachers and students of the Ukrainian and Lublin Catholic Universities. Joint scientific and educational events are organized, joint projects are implemented, positively influencing cooperation in the religious and cultural sphere of interstate relations.

The relations between Ukraine and Poland are complicated by some issues that have been exacerbated recently by internal and external factors. Particularly painful in the public consciousness were and still remain mutual claims and allegations related to the confrontation between the Ukrainians and the Poles during the World War II (Volyn tragedy) and the notorious Wisła Operation. The reasons and the sequence of the notorious events, as well as the scale of the Volyn events: from 30 thousand to 100 thousand (according to other figures - up to 500 thousand (Davies, N. 1987; Motyka, G. 2011) of the dead Poles, according to the Polish side, and from 15 to 20 thousand according to the estimations of Ukrainian historians remain contradictory to the scientists and politicians (Боляновський, А. 2013, с. 131) Even the names of these events differ in Ukrainian and Polish historiography (Volyn tragedy and Volyn massacre respectively). The groundbreaking attempts to understand the scale of the tragedy took place in 1992, when a Polish delegation arrived in Ukraine to conduct field-based research. Since 1997, Ukraine has also begun historical searches on this topic within the Government Commission on the problem of OUN-UIA. In addition, since the late 1990s, a joint commission of Ukrainian and Polish historians has been active to cover research on this topic. The work of this commission revealed radical differences in the interpretation and assessment of the scale of the tragedy by Polish and Ukrainian specialists, in particular, the trend to exaggerate or diminish the number of victims on both sides, as well as disputes regarding the sequence of events and causal relationships.

Despite the existing discrepancies, some compromises have been reached at the political level. Thus, in 1997 the Joint Statement of the Presidents of Ukraine and the Republic of Poland «For Understanding and Unity» was published, where the parties agreed that concealing and unilateral interpretation of facts would not mitigate the pain of the victims and their relatives, and would not contribute to a deepening of the understanding between our peoples as well as emphasized the importance of overcoming the bitterness in the historical memory of many Ukrainians and Poles (Спільна заява... 21.05.1997). In 2003 another Joint Declaration «On Reconciliation at the $60^{\text {th }}$ Anniversary of the Tragic Events in Volyn» was adopted, where both presidents praised the victims of bloody fratricidal conflicts and expressed their compassion for their families, as well as emphasized the need for a common search for the historical truth about a tragedy in Volyn and a 
public moral condemnation of the perpetrators of crimes committed against the Ukrainian and Polish peoples (Спільна заява... 11.07.2003).

Despite the positive steps towards historical reconciliation, the further path to this process was rather ambiguous. Thus, in July 2009, the Sejm of Poland in its resolution stated that the OUN-UIA in 1941-1943 carried out an anti-Polish campaign - massacres of ethnic cleansing and genocide nature. This wording was repeated in 2013, when the Sejm of Poland adopted the resolution devoted to the $70^{\text {th }}$ anniversary of the Volyn tragedy. This document was adopted by 263 votes, 33 were «against», 146 abstained. Moreover, the opposed parties whose members voted against or abstained stressed the rigid version of the resolution.

The reaction of Poland to the award of Stepan Bandera the title of «Hero of Ukraine» in 2010 was ambiguous. For example, the European Parliament on the submission of Polish representatives officially regretted this decision (resolution RC-B7-0116/2010 of February 17, 2010). Minister of the Office of the President of Poland M. Gandzlik stated: «We were surprised to perceive the decision of the President of Ukraine on Stepan Bandera. We relied on great delicacy from our Ukrainian partners. Poland has repeatedly expressed its objections in the talks with Ukrainian partners regarding respect for Stepan Bandera and members of the UIA. For the Poles, Stepan Bandera is an ambiguous figure» (Янукович не обіцяв... 02.03.2010). At the same time, the head of the delegation of the European Parliament on cooperation with Ukraine, P. Koval, a Pole, emphasized that he considers the situation with awarding S. Bandera with the highest Ukrainian state distinction exclusively internal issue of Ukraine (Янукович не обіцяв... 02.03.2010).

In recent years, the desire of the Ukrainian political elite to reconcile with Poland on the issue of assessing historical events has become even more significant. Thus, in 2014, President of Ukraine Petro Poroshenko expressed his apologies for the Volyn tragedy during the speech in the Polish parliament. And in early June 2016, well-known Ukrainians, among them Presidents of Ukraine Leonid Kravchuk and Viktor Yushchenko, the head of the UOC - Kyivan Patriarchate Filaret, the head of the Ukrainian Greek Catholic Church Sviatoslav Shevchuk, addressed an open appeal to the leaders of Poland and all Polish society with apologies for the Volyn tragedy and appeals to the Ukrainians and the Poles to treat each other as brothers. An open letter also addressed an appeal to Polish politicians with demands «to stop any impulsive political declaration, the approval of which is not painful, but only allows our common enemies to use against Poland and Ukraine» (Українці написали ... 03.06.2016).

The answer to this appeal was an open letter entitled «Brothers-Ukrainians», published in the Polish press, signed by 40 reputable representatives of the Polish people, among them three Presidents: Lech Wałęsa, Aleksander Kwaśniewski 
and Bronisław Komorowski, many Polish political, social and cultural leaders and journalists. In the reply letter the Polish side thanked the Ukrainians «for the sake of not limiting their responsibility for the injustices committed by the Poles in the 1940s», and also honored the victims of «fratricidal Polish-Ukrainian conflicts» and apologized for the «injustices caused» by the Poles to our «brothers-Ukrainians» (Польскі депутати... 20.06.2016).

Despite the declared desire for reconciliation, the assessment of tragic events in the Volyn from time to time becomes a subject of speculation, both by the Ukrainian and the Polish side. For example, in February 2016, leader of the Polish pro-government party «Right and Justice» Jarosław Kaczyński stated in an interview with one of the Polish publications that during World War II the Ukrainians «surpassed the Germans in their brutality against the Poles». He also noted that excessive «banderization» in the country could hinder the Euro-integration processes: «This is a matter of a certain choice of Ukraine. I clearly told Mr. Poroshenko that he would not join Europe with Bandera. This is clear to me, and we have shown so much patience, but there are limits for everything» (Україна з Бандерою... 06.02.2017).

Although it is obvious that this statement has nothing to do with the official position of the European Union, it nevertheless demonstrates the ability of the Polish political elite to use the methods of blackmail to influence Ukraine's internal policy. Such views in Poland are not prevailing; there are many Poles, political and scientific elites who emphasize the right of Ukraine to be independent and free in assessing its own past and in resolving its future. Nevertheless, some experts from Europe and, in fact, from Ukraine say that it is necessary to revise historical science and historical contexts that are related to the UIA - in particular, the «subversion» of World War II and the search for another positive interpretation of the role of Stepan Bandera in the struggle for Ukraine's independence. Thus, many successful steps have been taken for Ukrainian-Polish understanding, harmonization and interpretation of common history. However, the outcome in this important issue for both peoples has not yet been made. We hope that in the future, both sides will find the opportunity to work out and agree on a solution to this important problem that will be arranged by both sides.

One more problematic issue of bilateral relations is the facilities of places of national memory, especially the cemeteries of war victims and political repressions. In 1994, the Intergovernmental Agreement was signed on the protection of places of memory and burial of war victims and political repressions. This document signing accelerated the process of organizing custody of national memory places. Thus, in 2000 a Memorial Complex was opened for Polish officers in Kharkiv shot by the NKVD in 1940. The issue of the burial of Lviv Orliata in the Lyc- 
hakiv cemetery of Lviv was more complicated. The desire of the Polish side to restore the Polish historical pantheons on the Ukrainian territory was perceived by the Ukrainian population as a claim of the Poles to return to the «cresy land» (Стрільчук, Л. 2013, с. 178). For more than 10 years, complex Polish-Ukrainian negotiations continued, which demonstrated diametrically different views of the parties on the problem of reconstruction and opening the complex. Finally, in June 2005, with the participation of the Presidents of Poland and Ukraine in the Lychakiv cemetery, Memorial of dead soldiers of the Ukrainian Galician Army and the Memorial to Orliata were opened.

For a long time the situation with the Ukrainian burials in Poland remained complicated. For more than half a century, whole graveyards and graves with Ukrainian symbols have been destroyed. Obelisk victims of the «Wisła» Operation were treated as illegal, graves to UIA soldiers with the corresponding inscriptions were considered destroyed, the tablets were dismantled («Воїнам УПА»... 28.04.2011). However, times have changed, and since 1989, the Ukrainian communities in Poland have begun gradually restoring such burial grounds. Thus, at the end of the 1990s and early 2000, the military cemetery of the Sich Riflemen in Pikulića, near Przemysl, was restored. In 2000 there were reburied 47 UIA soldiers exiled from other villages. Since 1995, the Ukrainian community in Przemysl tried to streamline the abandoned cemetery with Ukrainian burials in the village of Pavlokom. After years of efforts in 2006, with the participation of the Presidents of both countries, a memorial complex dedicated to the residents of the village of Pavlokomy murdered in 1945 by the Army of Craiova was opened. The search and ordering of Ukrainian burials in Poland is being carried out by the efforts of the Ukrainian community of Poland and volunteers, because Ukraine does not allocate significant funds to this process. Consequently, it is not about writing a complete register of Ukrainian graves in Poland. Nevertheless, the Ukrainian side has done a lot to restore the memory of the dead and to organize the Ukrainian burials in the Polish territory.

One more problematic issue is securing rights of the Ukrainians in Poland and the Poles in Ukraine. Today, approximately 145 thousand Poles live in Poland, according to various data from 150 thousand to 500 thousand Ukrainians permanent residents, as well as more than 800 thousand workers are in the Polish territory (Шанси і проблеми... 2017). Due to resettlement and border changes after World War II, Polish and Ukrainian minorities usually do not live close to the border and do not form the majority in any territorial unit that is atypical for Central and Eastern Europe. Since the functioning of the Ukrainian community in Poland and Poland in Ukraine is a complex issue and requires a separate study, we will consider only a few narrow issues. 
For example, several dozen Ukrainian non-governmental organizations operate in Poland, the largest of which are the Ukrainian Association of Poles, the Union of the Ukrainians in Podlasie, the Lemko Association, the Ukrainian Society, the Ukrainian Teachers' Association, the Ukrainian Culture Foundation, the Union of Ukrainian Women of Poland. There are 5 complexes of schools with the study of certain subjects in the Ukrainian language, as well as 140 Ukrainian language teaching units in Poland (Українська громада... 05.2017). Since 2007 the intercity school of Ukrainian language has been operating in Warsaw. More than 100 children of migrant workers from Ukraine and from Ukrainian families of Polish citizens study there.

Due to events in Eastern Ukraine, the number of the Ukrainians working or studying in Poland has increased significantly. Although the Ukrainians work mainly on low-skilled positions - construction, services and trade, agriculture and manufacturing, the number of specialists in the field of IT technologies, physicians and others has recently increased. The population and leaders of Poland generally have a positive attitude towards the flow of Ukrainian migrants, and there are several reasons for this: the country's economy is developing rapidly, the country has been experiencing a demographic decline for several years, and the Ukrainians are close to the Poles culturally and mentally. In addition, the Ukrainians partially filled the demographic niches of Poles, which arose when millions of Polish citizens left the country in search of better life, mainly to Western Europe. However, the issue of labor migration of the Ukrainians to Poland has recently become political. So, since the middle of 2015, Polish politicians has begun to use the term «refugee» with regard to the Ukrainians who came to Poland to work. This was primarily due to efforts to avoid quotas for the resettlement of refugees from Asia and Africa. However, after the talks between the two countries at the diplomatic level and publications in the Polish media that only $18 \mathrm{Uk}-$ rainians actually received refugee status in 2015-2016 (Ukraińcy w Polsce 2017... 22.06.2017), Polish politicians began to avoid similar stamps.

The factor of being Ukrainian as a threat to Polish nationalists and radical forces that protest against the presence of any foreigners in the country is still used. In the Polish media, publications often show that labor migrants from Ukraine bring infectious diseases to Poland, many of whom are ex criminals, that the Ukrainians are dumping labor remuneration in Poland and taking jobs from the Poles. All this exacerbates the difficult relationship between the Ukrainians and the Poles and requires an integrated, moderate decision to reduce the tension between the representatives of our nations.

As for the Polish ethnic minority in Ukraine, it faces less problems. Since the late 1980's, more than 50 Polish non-governmental organizations have been fun- 
ctioning in Ukraine, among them the following are: the Union of Polish Poles, the Polish Society of Polish Culture, the Polish Cultural and Educational Society in Ternopil, the Y. Slatskii Society for the Revival of Polish Culture in Kremenets, the A. Mickiewicz Society of Polish Culture in Kyiv, the A. Mickiewicz Society of Polish Culture in Chernivtsi, the F. Karpinskyi Society of Polish Culture in Ivano-Frankivsk, the Yeva Filinska Society of Polish Culture of the Volyn Territory in Lutsk, the Wladyslaw Stanislaw Reymont Polish Culture Society in Rivne and others. Currently, the biggest issue that concerns the Polish community in Ukraine is the «language» issue - the Law «On Education», adopted in September 2017, forbids teaching in the languages of national minorities and indigenous peoples. Only the opportunity to create classes in Ukrainian schools, where the studies wi11 be conducted in the language of the national minority, along with the state language, remains. Studying the language of the indigenous people or national minority is guaranteed in schools or through national cultural societies. This law has caused ambiguous reaction in the world community. Oddly enough, the position of Poland in this regard was moderate. The statement of the Ministry of Foreign Affairs of Poland states that the changes in the Ukrainian law did not become a surprise to the Polish side, but the ministry will closely monitor the implementation of the law and take all necessary measures to enable the Poles in Ukraine to study in their native language (У Варшаві... 17.09.2017). Such a moderate reaction is likely to be related to a relatively small number of students (1785 people) learning the Polish language. Consequently, the problems faced by the Ukrainian diaspora in Poland and the Polish diaspora in Ukraine are quite different in character. The solution to these problems is primarily due to the political situation inside the country. The positive point is the cultural and mental integrity of the Ukrainians and the Poles, which allows them to co-exist quite comfortably within national communities.

Conclusions. Given the research set forth in this article, the following conclusions can be made. Firstly, cultural and humanitarian cooperation positively influences intergovernmental relations in other spheres - trade and economic, political, and security. Due to cooperation in scientific, educational, religious, medical, cultural and artistic industries interpersonal contacts are established between representatives of different nations, problem issues are solved, the number of exchanges of specialists and youth is increasing, acquaintance of societies with cultural heritage and traditions takes place. Secondly, the development of cooperation between Ukraine and Poland is the most dynamic in the field of science, education and art. Poland actively engages Ukrainian students, academics and scholars in its curricula, shares experience in the field of innovation and educational reform. Cultural and artistic cooperation takes place through the organization of festivals, exhibitions of Ukrainian ar- 
tists in Poland and vice versa, as well as through touring activities of amateur and professional teams. Thirdly, the state visit of Pope John Paul II, a Pole, made a tremendous influence on the development of bilateral relations. The arrival of the Pope and his commitment to Ukraine helped both sides to reconcile and relieve tension in bilateral relations, as well as to intensify cooperation of religious communities of both countries. In spite of positive dynamics, the bilateral issues are the problem issues, which are primarily related to the uneasy historical past of our states. Nevertheless, in the presence of political will and consistency of decisions, Ukraine and Poland are able to overcome the existing contradictions and further strengthen cooperation in various spheres of interstate relations.

Боляновський, А. 2013. Проблема кількості польських жертв Волинської трагедії 1943 року, Украӥна-Польща: історична спадщина і суспільна свідомість. Вип. 6. 131.

Візит папи Римського до Украӥни, [Online]. Режим доступу: http://bit.ly/2jeb8Jj

«Воїнам УПА» чи «повстанцям»? Як поляки реагують на меморіальні написи. 28.04.2011. Українська правда, [Online]. Режим доступу: http://www.istpravda.com

Договір між Украӥною і Республікою Польщею про добросусідство, дружні відносини і співробітництво від 18.05.1992, [Online]. Режим доступу: http://bit.ly/2BcmwxF

Завітневич, Н. Г. 2008. Гуманітарний чинник в украӥнсько-польських міждержавних відносинах : дис. ...к. політ. н.: 23.00.04. Політичні проблеми міжнародних систем та глобального розвитку. Київ.

Зленко, А. М. 2004. Дипломатия и политика. Украина в процессе динамичных геополитических перемен. Харьков: Фолио.

Знахоренко, О. М. 2005. Стратегічне партнерство в украӥнсько-польських відносинах : дис. канд. політ. наук: 23.00.04. Політичні проблеми міжнародних систем та глобального розвитку. Київ.

Культурно-гуманітарне співробітництво між Украӥною та Польщею, [Online]. Режим доступу: http://bit.ly/2n9fDbI

Лишко, В. В. 2002. Украӥнсько-польські зв 'язки в галузі культури (1991-1999рр.): дис... канд. іст. н.: 07.00.01. Історія України. Київ.

Лікарі на експорт, [Online]. Режим доступу: http://bit.ly/2B1HIFI

Медведчук, Н. 2001. Участь Волині в реалізації культурно-освітніх програм єврорегіону «Буг». Збірник навчально-методичних матеріалів і наукових статей Волинського національного університету імені Лесі Украӥнки. Луцьк. Вип. 6. 135-139.

Наконечний, В. І. 2013. Система українсько-польських міждержавних взаємовідносин у пострадянський період (1991-2004 pp.): особливості становлення та структура. Наукові праці. Політологія. Вип. 200. Т. 212. 33-37.

Польські депутати відповіли на лист української інтелігенції про примирення. 20.06.2016. Радіо свобода, [Online]. Режим доступу: http://bit.ly/2hQ19NC

Польсько-українська програма зі стажування та розвитку для українських лікарів у Польщі 26.01.2016, Відкритий діалог, [Online]. Режим доступу: http://bit.ly/2BcoD14

Спільна заява Президентів України і Республіки Польща «До порозуміння і єднання» від 21.05.1997, [Online]. Режим доступу: http://bit.ly/2hTpiml

Спільна заява Президентів України та Республіки Польща «Про примирення в 60-у річницю трагічних подій на Волині» від 11.07.2003, [Online]. Режим доступу: http://bit.ly/2jMzSwh 
Стрільчук, В. В. 2015. Україна - Польща: транскордонне співробітнищтво у культурній сфері (90-ті роки XX - початок XXI століття): дис. ... канд. іст. наук: 07.00.01. Історія України. Луцьк.

Стрільчук, Л. В., Стрільчук, В. В. 2013. Інституційні складові українсько-польських гуманітарних взаємин і співробітництва: монографія. Луцьк: Волинські старожитності.

У Варшаві - про ситуацію в Україні, [Online]. Режим доступу: http://bit.ly/2hHXQEq

Україна з Бандерою до Європи не увійде: Качинский. 06.02.2017. Європейська правда, [Online]. Режим доступу: http://bit.ly/2zW0tge

Угода між Урядом Украӥни і Урядом Республіки Польщза про співробітництво в галузі культури, науки та освіти від 20.05.1997, [Online]. Режим доступу: http://bit.ly/2hSINwE

Украӥнська громада в Республіці Польщ̧а, [Online]. Режим доступу: http://bit.ly/2hH887P

Українсько-польські дні освіти, науки та інновацій в Києві, [Online]. Режим доступу: http://bit.ly/2B329BM

Українці написали лист прощення до поляків, 03.06.2016. 5 канал, [Online]. Peжим доступу: http://bit.ly/2jLi58w

Шанси і проблеми: як ставляться до українських трудових мігрантів у Польщі. 30.05.2017. CвimUA, [Online]. Режим доступу: http://bit.ly/2zXLrXU

Щурко, У. В. 2014. Напрями українсько-польської транскордонної співпраці в гуманітарній сфері. Соціально-економічні проблеми сучасного періоду Украӥни. Вип. 4 (108). 179.

Янукович не обіцяв відібрати звання у Бандери. 02.03.2010. Українська правда, [Online]. Режим доступу: http://bit.ly/2jJRxET

Davies, N. 1987. Buczacz. «Neither Twenty Million, nor Russians, nor War Dead...». The Independent. 29 December, [Online]. Режим доступу: http://bit.ly/2hJUm4s

Fedorowicz, K. 2004. Ukraina w polskiej polityce wschodniej w latach 1989-1999. Poznań: Uniwersytet im. Adama Mickiewicza.

Historia harcerstwa, [Online]. Режим доступу: http://bit.ly/2hQ8Wek

Motyka, G. 2011. Od rzezi wotyńskiej do Akcji «Wisła». Konflikt polsko-ukraiński 1943-1947. Kraków, 2011.

Olszański, T. A. 2002. Pryszłość stosunków polsko-ukraińskich między Lwowem a Donieckiem (uwagi polemiczny). Ukraina a Polska — partnerstwo strategiczne. Historia. Czas terażniejszy. Przyszłość. Cz. 2. 53-58.

Ukraińcy w Polsce 2017. Kim są i czego poszukują? 22.06.2017. Aleteia, [Online]. Peжим доступу: http://bit.ly/2AZcSgU

Bolianovskyi, A. 2013. Problema kilkosti polskykh zhertv Volynskoi trahedii 1943 roku, Ukraina-Polshcha: istorychna spadshchyna i suspilna svidomist. Vyp. 6. 131.

Vizyt papy Rymskoho do Ukrainy, [Online]. Rezhym dostupu: http://bit.ly/2jeb8Jj

«Voinam UPA» chy «povstantsiam»? Yak poliaky reahuiut na memorialni napysy. 28.04.2011. Ukrainska pravda, [Online]. Rezhym dostupu: http://www.istpravda.com

Dohovir mizh Ukrainoiu i Respublikoiu Polshcheiu pro dobrosusidstvo, druzhni vidnosyny $i$ spivrobitnytstvo vid 18.05.1992, [Online]. Rezhym dostupu: http://bit.ly/2BcmwxF

Zavitnevych, N. H. 2008. Humanitarnyi chynnyk v ukrainsko-polskykh mizhderzhavnykh vidnosynakh: dys.... k. polit. n.: 23.00.04. Politychni problemy mizhnarodnykh system ta hlobalnoho rozvytku. Kyiv. 
Zlenko, A. M. 2004. Diplomatija i politika. Ukraina v processe dsnamschnykh geopoliticheskikh peremen. Kharkov: Folio.

Znakhorenko, O. M. 2005. Stratehichne partnerstvo v ukrainsko-polskykh vidnosynakh: dys. kand. polit. nauk: 23.00.04. Politychni problemy mizhnarodnykh system ta hlobalnoho rozvytku. Kyiv.

Kulturno-humanitarne spivrobitnytstvo mizh Ukrainoiu ta Polshcheiu, [Online]. Rezhym dostupu: http://bit.ly/2n9fDbI

Lyshko, V. V. 2002. Ukrainsko-polski zv'iazky v haluzi kultury (1991-1999 rr.): dys... kand. ist. n.: 07.00.01. Istoriia Ukrainy. Kyiv.

Likari na eksport, [Online]. Rezhym dostupu: http://bit.ly/2B1HIFI

Medvedchuk, N. 2001. Uchast Volyni v realizatsii kulturno-osvitnikh prohram yevrorehionu «Buh». Zbirnyk navchalno-metodychnykh materialiv i naukovykh statei Volynskoho natsionalnoho universytetu imeni Lesi Ukrainky. Lutsk. Vyp. 6. 135-139.

Nakonechnyi, V. I. 2013. Systema ukrainsko-polskykh mizhderzhavnykh vzaiemovidnosyn u postradianskyi period (1991-2004 rr.): osoblyvosti stanovlennia ta struktura. $\mathrm{Na}$ ukovi pratsi. Politolohiia. Vyp. 200. T. 212.33-37.

Polski deputaty vidpovily na lyst ukrainskoi intelihentsii pro prymyrennia. 20.06.2016. Radio svoboda, [Online]. Rezhym dostupu: http://bit.ly/2hQ19NC

Polsko-ukrainska prohrama zi stazhuvannia ta rozvytku dlia ukrainskykh likariv u Po1shchi 26.01.2016, Vidkrytyi dialoh, [Online]. Rezhym dostupu: http://bit.ly/2BcoD14

Spilna zaiava Prezydentiv Ukrainy i Respubliky Polshcha «Do porozuminnia i yednannia» vid 21.05.1997, [Online]. Rezhym dostupu: http://bit.ly/2hTpiml

Spilna zaiava Prezydentiv Ukrainy ta Respubliky Polshcha «Pro prymyrennia - v 60u richnytsiu trahichnykh podii na Volyni» vid 11.07.2003, [Online]. Rezhym dostupu: http://bit.ly/2jMzSwh

Strilchuk, V. V. 2015. Ukraina - Polshcha: transkordonne spivrobitnytstvo u kulturnii sferi (90-ti roky XX - pochatok XXI stolittia): dys. ... kand. ist. nauk: 07.00.01. Istoriia Ukrainy. Lutsk.

Strilchuk, L. V., Strilchuk, V. V. 2013. Instytutsiini skladovi ukrainsko-polskykh humanitarnykh vzaiemyn i spivrobitnytstva: monohrafiia. Lutsk: Volynski starozhytnosti.

U Varshavi - pro sytuatsiiu v Ukraini, [Online]. Rezhym dostupu: http://bit.ly/2hHXQEq

Ukraina z Banderoiu do Yevropy ne uviide: Kachynskyi. 06.02.2017. Yevropeiska prav$d a$, [Online]. Rezhym dostupu: http://bit.ly/2zW0tge

Uhoda mizh Uriadom Ukrainy $i$ Uriadom Respubliky Polshcha pro spivrobitnytstvo $v$ haluzi kultury, nauky ta osvity vid 20.05.1997, [Online]. Rezhym dostupu: http://bit.ly/2hSINwE

Ukrainska hromada $v$ Respublitsi Polshcha, [Online]. Rezhym dostupu: http://bit.ly/2hH887P

Ukrainsko-polski dni osvity, nauky ta innovatsii v Kyievi, [Online]. Rezhym dostupu: http://bit.ly/2B329BM

Ukraintsi napysaly lyst proshchennia do poliakiv, 03.06.2016. 5 kanal, [Online]. Rezhym dostupu: http://bit.ly/2jLi58w

Shansy i problemy: yak stavliatsia do ukrainskykh trudovykh mihrantiv u Polshchi. 30.05.2017. SvitUA, [Online]. Rezhym dostupu: http://bit.ly/2zXLrXU

Shchurko, U 2014. Napriamy ukrainsko-polskoi transkordonnoi spivpratsi v humanitarnii sferi. Sotsialno-ekonomichni problemy suchasnoho periodu Ukrainy. Vyp. 4 (108). 179.

Yanukovych ne obitsiav vidibraty zvannia u Bandery. 02.03.2010. Ukrainska pravda, [Online]. Rezhym dostupu: http://bit.ly/2jJRxET 
Davies, N. 1987. Buczacz. «Neither Twenty Million, nor Russians, nor War Dead...». The Independent. 29 December, [Online]. Режим доступу: http://bit.ly/2hJUm4s

Fedorowicz, K. 2004. Ukraina w polskiej polityce wschodniej w latach 1989-1999. Poznań: Uniwersytet im. Adama Mickiewicza.

Historia harcerstwa, [Online]. Режим доступу: http://bit.ly/2hQ8Wek

Motyka, G. 2011. Od rzezi wotyńskiej do Akcji «Wisła». Konflikt polsko-ukraiński 1943-1947. Kraków, 2011.

Olszański, T. A. 2002. Pryszłość stosunków polsko-ukraińskich między Lwowem a Donieckiem (uwagi polemiczny). Ukraina a Polska - partnerstwo strategiczne. Historia. Czas terażniejszy. Przyszłość. Cz. 2. 53-58.

Ukraińcy w Polsce 2017. Kim są i czego poszukują? 22.06.2017. Aleteia, [Online]. Rezhym dostupu: http://bit.ly/2AZcSgU

УДК 94(477)«1932-1933»

DOI: $10.20535 / 2307-5244.45 .2017 .117736$

\section{Б. Кліо}

Канадський інститут украӥнських студій Альбертського університету

Б. Клід

Канадський інститут українських студій Альбертського університету

WHY IS IT IMPORTANT TO STUDY THE HISTORY OF THE HOLODOMOR - THE GENOCIDE OF THE UKRAINIAN PEOPLE

\section{Чому важсливо вивчати історії Голодомору - геноциду украӥнського народу}

The article covers the main stages of research in the Ukrainian Diaspora of the Holodomor of 1932-33 and its influence on the formation of Ukrainian identity. The main directions for further study of this important scientific problem for Ukraine are indicated

Keywords: The Holodomor of 1932-1933, Identity, Ukrainian Diaspora.

В статті висвітлюються основні етапи дослідження в украйнській діаспорі Голодомору 1932-1933 рр. та його впливу на формування украӥнської ідентичності. Визначені основні напрями подальшого дослідження важливої для України наукової проблеми.

Ключові слова: Голодомор 1932-1933 рр., ідентичність, українська діаспора. 